\title{
Antibacterial efficacy of lactic acid bacteria and bacteriocin isolated from Dadih's against Staphylococcus aureus
}

\author{
Usman PATO $^{1 \star}$, Emma RIFTYAN ${ }^{1}$, Dewi Fortuna AYU ${ }^{1}$, Nia Naidya JONNAIDI ${ }^{1}$, Mimi Sri WAHYUNI ${ }^{1}$, Jeska \\ Aryaningsih FERUNI ${ }^{1}$, Mosaad Attia ABDEL-WAHHAB ${ }^{2 *}$ (D)
}

\begin{abstract}
Bacteriocin, a peptide produced by lactic acid bacteria (LAB) widely used as a natural and safe preservative in food products. This work aimed to evaluate the characterization of bacteriocin from dadih's LAB and to study its antimicrobial activity against Staphylococcus aureus. Supernatant from 12 LBA strains could inhibit S. aureus growth with different inhibition zones. Only nine strains showed inhibition zones of $>3.5 \mathrm{~mm}$ and were further evaluated for their antibacterial compounds. Three strains had antimicrobial activity derived from organic acids, especially lactic acid, and six strains had antimicrobial compounds in the form of bacteriocin. Bacteriocin strain R-55 showed the highest activity against S. aureus, with an average inhibition zone of $8.43 \mathrm{~mm}$. The molecular weight of the purified isolated bacteriocin from the R-55 strain was $14.4 \mathrm{kDa}$. Bacteriocin obtained from St. faecalis subsp. liquefaciens R-55 is a promising natural preservative to prevent the growth of S. aureus as foodborne pathogens.
\end{abstract}

Keywords: bacteriocin; dadih; lactic acid bacteria; Staphylococcus aureus; antibacterial; natural preservative.

Practical Application: Bacteriocin from lactic acid bacteria for food bio preservatives.

\section{Introduction}

Staphylococcus aureus is the major pathogenic bacteria that infect humans and animals, resulting in several clinical manifestations of the pathogen, including the infection of superficial skin and soft tissue, sepsis, pneumonia, and endocarditis (Tong et al., 2015). These pathogenic bacteria are prone to be resistant to different antibiotics. Infections are prevalent in the hospital-acquired and community-acquired environment, and the treatment is still challenging to achieve because of the development of multi-drug resistant bacterial strains such as Methicillin-Resistant Staphylococcus aureus (MRSA) (Boucher \& Corey 2008). MRSA is resistant to most $\beta$-lactam antibiotics due to the penicillin-binding protein encoded by the mecA gene (Chambers, 1997). Moreover, MRSA can epidemically spread in livestock and hospitals, societies (Ho et al., 2012; Vandendriessche et al., 2014). The risk of transmission of MRAS from animals to human attracted public health concern since the observation of the livestock-associated MRSA from pig belonging to LA-MRSA CC398 (Clonal Complex 398) was reported in Netherland early in the twentieth century (van Loo et al., 2007; Garcia-Graells et al., 2012).

This organism is robust so that it can grow on many types of food that are processed or stored incorrectly, and the infection causes diseases via the production of different enzymes and enterotoxins (SEs) or by the direct invasion and destruction of the tissues of the human body (Taddesse et al., 2014). This SEs is one of those compounds causing staphylococcal food poisoning (SFP) by S. aureus (Rasooly \& Friedm, 2012) and consists of nine groups of heat-stable SEs, namely SEH, SEB, SEA, SEC, SEE, SED, SEG, SEJ, and SEI (Argudín et al., 2010). It was estimated that about $20-30 \%$ of the human population are carriers for S. aureus (Tong et al., 2015), which are coexist with human microbiota and cause abscesses and the infections of the skin (Carroll et al., 2017), respiratory system (Payne \& Benninger, 2007; Vickery et al., 2019) and Staphylococcal foodborne disease (Kadariya et al., 2014). Heat treatment on food can kill S. aureus, but heating cannot deactivate SEs so that these toxins remain in the food, which in turn causes SFP (Hu \& Nakane, 2014). Therefore, it is vital to stop the growth of $S$. aureus in food, which can subsequently produce toxins.

Several synthetic chemical preservatives are used commercially, including salts, sugar, butylated hydroxyl toluene (BHT), butylated hydroxy-anisole (BHA), tert-butyl hydroquinone (TBHQ), nitrites, sodium nitrate, calcium propionate, and sulfite compounds such as sulfur dioxide, sodium bisulfite, disodium and potassium hydrogen (Walsh, 2007). The massive use of these synthetic preservatives in the food sector is mainly because these preservatives are commercially distributed in chemical stores. However, these chemicals are not always safe for human consumption because their overuse can cause health problems ranging from allergies and asthma to cancer (Dicks et al., 2017). Therefore, the development of safe, natural preservatives is critically needed. LABs produce various inhibitor compounds as primary and secondary metabolic end products like bacteriocins, hydrogen peroxide, and organic acids, especially lactic acid 
(Sankar et al., 2012; Zhou et al., 2014). Bio-preservation is a concept of using $\mathrm{LAB}$ and its antimicrobial products, including bacteriocin, to inhibit the growth of pathogenic and spoilage microbes in food (Stiles, 1996). Bacteriocin is peptide molecules consisting of 12-100 amino acids with amphiphilic characteristics, cationic net charge, synthesized, and released to act extracellularly and have activity against other bacteria (Rios et al., 2016). These peptides are considered GRAS (generally recognized as safe) and continue to interest many researchers because they have potential use in the pharmaceutical and food industries. In the food industry, bacteriocin has long been used to prevent food spoilage and foodborne diseases (Perez et al., 2014). These bacteriocins have many characteristics such as high stability, low toxicity, and a narrow to a broad spectrum of activity, making them suitable for clinical applications as safe, natural food preservatives (Bharti et al., 2015; Kitagawa et al., 2019; Zacharof \& Lovitt, 2012). Enterococcus, lactobacillus, pediococcus, leuconostoc, and carnobacterium are genera of LAB that commonly produce bacteriocins (Bharti et al., 2015). LAB such as lactobacillus sp., streptococcus sp., leuconostocsp., and Lactococcussp. isolated from dadih, a kind of fermented buffalo milk product, have been tested for their antimutagenic activity against different mutagens (Hosono et al., 1990a) and antimicrobial activity against listeria monocytogenes (Pato et al., 2020). The current work aimed to assess the antimicrobial activity of dadih's LAB and to characterize the bacteriocin responsible for the antimicrobial activity against $S$. aureus.

\section{Materials and methods}

\subsection{Media and chemicals}

The media used for the activation of $\mathrm{LAB}$ and $S$. aureus FNCC-15 (Food and Nutrition Culture Collection) cultures and the antimicrobial test were MRS Broth (MRSB), Nutrient Broth (NB), and Nutrient Agar (NA). The chemicals used include ammonium sulfate, phosphate buffers, and chemicals for the molecular weight analysis of bacteriocin and amylase and proteolytic enzymes. All the media and chemicals were purchased from Merck and Sigma Aldrich (Singapore).

\subsection{Pathogenic bacteria and Dadih'sLAB}

The gram-positive pathogenic bacterium used was Staphylococcus aureus FNCC-15 was obtained from the Laboratory of Food Microbiology, Center for Food and Nutrition Studies, Universitas Gadjah Mada, Yogyakarta, Indonesia. Dadih samples were purchased from Bukittingi, West Sumatera, Indonesia. LAB was isolated and identified according to Hosono et al. (1990b) using $\mathrm{API}^{\circledR} 50 \mathrm{CH}$ test.

\subsection{Activation of the LAB culture and Staphylococcus aureus FNCC-15}

The activation of LAB and $S$. aureus cultures was carried out according to the method described in our previous work (Pato et al., 2020). Each LAB culture was taken as much as $0.1 \mathrm{~mL}$ and put into a test tube containing $5 \mathrm{~mL} \mathrm{MRSB}$, then shaken evenly and incubated aerobically for $18 \mathrm{~h}$ at $37^{\circ} \mathrm{C}$.
However, $S$. aureus was activated by inoculating $0.1 \mathrm{~mL}$ of the bacterial suspension into $5 \mathrm{ml} \mathrm{NB}$, shaken evenly, and incubated aerobically for $18 \mathrm{~h}$ at $37^{\circ} \mathrm{C}$.

\subsection{In vitro antimicrobial activity of $L A B$}

$\mathrm{LAB}$ cultures were grown in MRSB and incubated aerobically for $24 \mathrm{~h}$ at $37^{\circ} \mathrm{C}$; however, the indicator bacterium, S. aureus, was grown in $\mathrm{NB}$ for $24 \mathrm{~h}$ at $37^{\circ} \mathrm{C}$. One hundred $\mu \mathrm{l}$ of pathogenic microorganisms were placed and spread using glass hockey sticks on MRSA surface. The sterile disc papers were dipped into the LAB supernatants and sterile MRSB as a negative control. Disc papers with a diameter of $6 \mathrm{~mm}$ were then placed on the surface of the MRSA plates that been previously inoculated with indicator bacteria. The plates were then incubated at $37^{\circ} \mathrm{C}$ for $24 \mathrm{~h}$, and the diameter of the growth inhibition zone was measured (Syukur et al., 2014a).

\subsection{Production of bacteriocin}

Dadih LABs were propagated in MRSB by adding inoculum as much as $10 \%$ of the active culture and incubation at $37^{\circ} \mathrm{C}$ for $24 \mathrm{~h}$. Then, the whole broth was centrifuged at 10,000 rpm for $15 \mathrm{~min}$ to get the supernatant. The supernatant separated from the cells was then added with $70 \%$ ammonium sulfate and put in the refrigerator $\left(4^{\circ} \mathrm{C}\right)$ for $12 \mathrm{~h}$ to precipitate the protein. This mixture was centrifuged at $10,000 \mathrm{rpm}$ at $4{ }^{\circ} \mathrm{C}$ for $30 \mathrm{~min}$ to obtain crude bacteriocin (Sankar et al., 2012).

\subsection{Bacteriocin characterization}

\section{Effect of $p H$}

The effect of $\mathrm{pH}$ from 3 to 11 was carried out by adding $0.5 \mathrm{ml}$ of bacteriocin into $4.5 \mathrm{~mL}$ of $\mathrm{NB}$ and then incubating for $30 \mathrm{~min}$ at $37^{\circ} \mathrm{C}$. After incubation, the antimicrobial activity of treated bacteriocin against $S$. aureus was assayed using the agar diffusion method (Syukur et al., 2014a).

\section{Effect of temperature}

The effect of heat treatment at 30 to $121^{\circ} \mathrm{C}$ was carried out by adding $0.5 \mathrm{ml}$ of bacteriocin into $4.5 \mathrm{~mL}$ of $\mathrm{NB}$ in test tubes. Each test tube was overlaid with paraffin oil and covered with aluminum foil to prevent evaporation during heating for $10 \mathrm{~min}$ at the temperature mentioned above. The antimicrobial activity of heated bacteriocins against $S$. aureus was carried out using the agar diffusion method (Syukur et al., 2014a).

\section{Effect of amylase and proteolytic enzymes}

The effect of amylase and proteolytic enzymes on the activity of bacteriocin was conducted according to the previous method (Zhou et al., 2014). The crude bacteriocin was treated with $5 \mathrm{mg} / \mathrm{ml}$ of amylase, trypsin, and proteinase, while phosphate buffer $(0.5 \mathrm{M}$, $\mathrm{pH}$ 7.0) was used as a control. The antimicrobial activity of the enzyme-treated bacteriocin against $S$. aureus was carried out using the agar diffusion method (Syukur et al., 2014b). 


\section{Purification and molecular weight determination of bacteriocin}

The crude bacteriocin was dissolved in a phosphate buffer (0.1 M, pH 7.0) and dialyzed in the same buffer at $4{ }^{\circ} \mathrm{C}$ for $12 \mathrm{~h}$. The dialyzed crude bacteriocin was then applied to the Sephadex LH-20 column $(2.0 \times 50 \mathrm{~cm})$, which had been prefiltered with the same phosphate buffer. The flow rate was set at $24 \mathrm{~mL} / \mathrm{h}$, and the fractions formed were collected as much as $10 \mathrm{ml}$ each. The fractions that showed high antimicrobial activity were concentrated using a lyophilizer and then measured their molecular weight. The bacteriocin's molecular weight was determined using $12 \%$ SDS-PAGE gel electrophoresis in the LKB Bromma 2050 Midget electrophoresis unit (Pharmacia Amersham Co). The gel then was stained using Coomassie Brilliant Blue R-250 and destained by washing with a mixture of acetic acid-methyl alcohol-water $(5: 5: 1 \mathrm{v} / \mathrm{v})$ for $12 \mathrm{~h}$. The low molecular marker (10-100 kDa) with six polypeptides was used as a marker (Rajaram et al., 2010).

\section{Statistical analysis}

The data obtained were analyzed using the SPSS 18.0 Program for Windows (Munich, Germany), including Analysis of Variance and Duncan New Multiple Range Test at the 5\% level.

\section{Results and discussion}

A total of $12 \mathrm{LAB}$ strains used in this study were isolated from dadih. The isolated LAB strains are Leu. Paramesenteroides R-8, St. cremoris R-14, St. faecalis subsp. Liquefaciens R-19, St. lactis subsp. Diacetylactis R-22, Leuconostoc para mesenteroides R-31, St. lactis subsp. diacetylactis R-41, St. lactis subsp. diacetylactis R-43, Leuconostoc para mesenteroides R-45, Leuconostoc para mesenteroides R-49, St. faecalis subsp. Liquefaciens R-55 and St. faecalis subsp. liquefaciens R-56. The inhibition zone of cell-free supernatant for the twelve strains of LAB against Staphylococcus aureus is shown in Figure 1. These results indicated the secretion of antibacterial compounds into the extracellular environment during LAB growth, as shown by the clear zone. The strains R-22, R-45, R-49, R-19 showed higher antimicrobial properties, while R-8, R-14, and R-31 showed lower antimicrobial properties. The difference in antimicrobial activity of the isolated 12 strains of LAB is likely due to differences in the amount of lactic acid or the type of bacteriocin produced by each LAB. These results are in agreement with the results reported by several investigators who reported that LABs can inhibit the growth of $S$. aureus (Syukur et al., 2014a, b; Othman et al., 2017). The current results also revealed that the strains $\mathrm{R}-8, \mathrm{R}-14$, and $\mathrm{R}-31$ showed the lowest antimicrobial activity, so these three BAL strains were no longer used in the next tests.

The antimicrobial compounds released during LAB growth are generally in the form of organic acids, especially lactic acid diacetyl, hydrogen peroxide, or proteinaceous bacteriocin (Bharti et al., 2015). To find out the antimicrobial compounds of the highest nine antimicrobial LABs, the tests were continued to estimate the sensitivity of their supernatant to various $\mathrm{pH}$ treatments, and the results are shown in Table 1. The supernatant of R-49 and R-56 lost their activity when the $\mathrm{pH}$ was adjusted from 7 to 11 . However, the activity of $\mathrm{R}-22$ was lost at $\mathrm{pH} 9$ to 11. These results suggested that organic acids, especially lactic acid which produced during the growth of LAB, play a role in inhibiting S. aureus growth. Several researchers have previously reported similar results about antimicrobial activity of organic acids produced by various strains of LAB, mainly lactic acid, against S. aureus (Pato et al., 2017).

The antimicrobial components of the other six LAB strains, R-19, R-32, R-43, R-45, R-49, and R-55, are most likely proteinous bacteriocin. This is characterized by no loss in the inhibitory

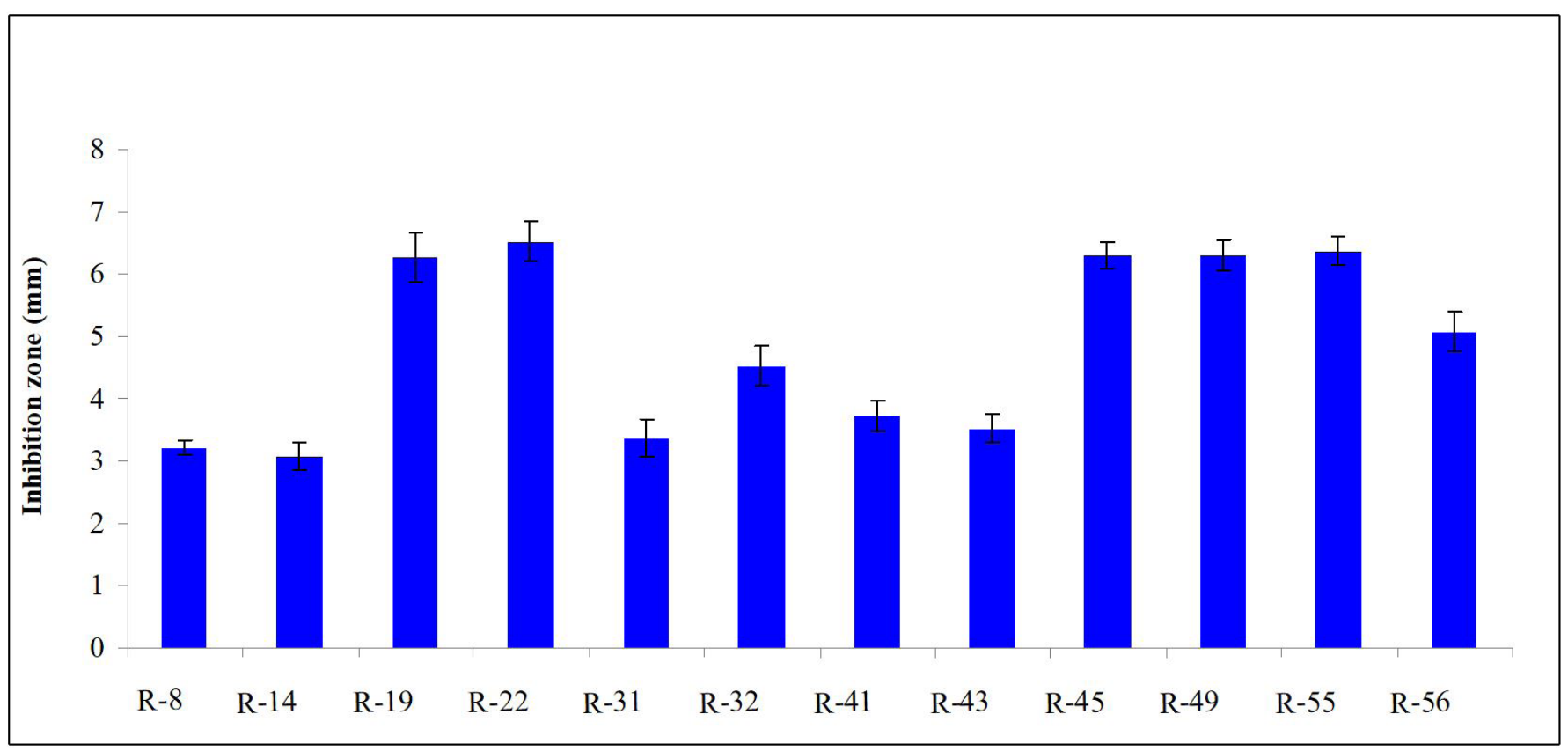

Figure 1. Antimicrobial activity of cell-free supernatant from dadih's lactic acid bacteria against Staphylococcus aureus. 
Table 1. Sensitivity of antimicrobial activity of supernatant from dadih's lactic acid bacteria against Staphylococcus aureus at various $\mathrm{pHs}$.

\begin{tabular}{|c|c|c|c|c|c|c|}
\hline \multirow{2}{*}{ Strains } & \multicolumn{6}{|c|}{ Inhibition zone (mm) } \\
\hline & Control & pH 3 & pH 5 & pH 7 & $\mathrm{pH} 9$ & $\mathrm{pH} 11$ \\
\hline $\mathrm{R}-19$ & $11.77^{\mathrm{c}}$ & $9.97^{\mathrm{b}}$ & $7.73^{\mathrm{a}}$ & $14.30^{\mathrm{d}}$ & $11.07^{\mathrm{bc}}$ & $14.00^{\mathrm{d}}$ \\
\hline $\mathrm{R}-22$ & $2.77^{\mathrm{b}}$ & $1.43^{\mathrm{ab}}$ & $2.77^{\mathrm{b}}$ & $0.87^{\mathrm{a}}$ & $0^{a \star}$ & $0^{\mathrm{a} *}$ \\
\hline $\mathrm{R}-32$ & $3.77^{\mathrm{a}}$ & $6.33^{c}$ & $5.10^{\mathrm{b}}$ & $9.07^{\mathrm{e}}$ & $7.00^{c}$ & $8.40^{\mathrm{d}}$ \\
\hline $\mathrm{R}-41$ & $7.87^{\mathrm{c}}$ & $8.63^{\mathrm{c}}$ & $3.97^{\mathrm{a}}$ & $6.97^{\mathrm{bc}}$ & $4.10^{\mathrm{a}}$ & $8.30^{\mathrm{c}}$ \\
\hline $\mathrm{R}-43$ & $6.07^{\mathrm{a}}$ & $7.60^{\mathrm{b}}$ & $7.10^{\mathrm{b}}$ & $11.00^{c}$ & $5.87^{\mathrm{a}}$ & $6.63^{\mathrm{ab}}$ \\
\hline $\mathrm{R}-45$ & $7.67^{\mathrm{b}}$ & $4.43^{\mathrm{a}}$ & $4.63^{\mathrm{a}}$ & $4,00^{\mathrm{a}}$ & $8.30^{c}$ & $8.40^{c}$ \\
\hline $\mathrm{R}-49$ & $3.43^{\mathrm{bc}}$ & $2.20^{\mathrm{b}}$ & $4.20^{c}$ & $0^{\text {a* }}$ & $0^{a *}$ & $0^{a \star}$ \\
\hline $\mathrm{R}-55$ & $9.37^{\mathrm{c}}$ & $10.20^{c}$ & $10.20^{c}$ & $6.43^{\mathrm{a}}$ & $5.53^{\mathrm{a}}$ & $7.30^{\mathrm{b}}$ \\
\hline $\mathrm{R}-56$ & $3.00^{\mathrm{b}}$ & $2.67^{\mathrm{b}}$ & $2.070^{\mathrm{b}}$ & $0^{a \star}$ & $0^{a \star}$ & $0^{\mathrm{a}^{*}}$ \\
\hline
\end{tabular}

${ }^{\star}$ Lost antimicrobial activity; Means followed by the lowercase letters in the same row indicate a significant difference $(\mathrm{P}<0.05)$.

Table 2. Sensitivity of antimicrobial activity of crude bacteriocin from dadih's lactic acid bacteria against Staphylococcus aureus at various heat temperatures.

\begin{tabular}{cccccccc}
\hline \multirow{2}{*}{ Strains } & \multicolumn{7}{c}{ Inhibition zone (mm) at different temperature } \\
\cline { 2 - 8 } & Control & $30^{\circ} \mathrm{C}$ & $50^{\circ} \mathrm{C}$ & $70^{\circ} \mathrm{C}$ & $90^{\circ} \mathrm{C}$ & $100^{\circ} \mathrm{C}$ & $121^{\circ} \mathrm{C}$ \\
\hline $\mathrm{R}-19$ & $6.42^{\mathrm{c}}$ & $8.12^{\mathrm{d}}$ & $7.00^{\mathrm{cd}}$ & $6.56^{\mathrm{c}}$ & $6.67^{\mathrm{c}}$ & $5.53^{\mathrm{b}}$ & $2.00^{\mathrm{a}}$ \\
$\mathrm{R}-32$ & $2.77^{\mathrm{b}}$ & $4.77^{\mathrm{c}}$ & $3.33^{\mathrm{b}}$ & $5.77^{\mathrm{c}}$ & $8.21^{\mathrm{d}}$ & $5.11^{\mathrm{c}}$ & $0.67^{\mathrm{a}}$ \\
$\mathrm{R}-41$ & $5.43^{\mathrm{b}}$ & $5.20^{\mathrm{b}}$ & $4.32^{\mathrm{b}}$ & $8.78^{\mathrm{c}}$ & $6.99^{\mathrm{bc}}$ & $7.32^{\mathrm{c}}$ & $1.00^{\mathrm{a}}$ \\
$\mathrm{R}-43$ & $4.99^{\mathrm{b}}$ & $5.87^{\mathrm{bc}}$ & $4.20^{\mathrm{b}}$ & $6.55^{\mathrm{c}}$ & $6.76^{\mathrm{c}}$ & $4.10^{\mathrm{b}}$ & $2.67^{\mathrm{a}}$ \\
$\mathrm{R}-45$ & $5.56^{\mathrm{c}}$ & $5.35^{\mathrm{c}}$ & $3.77^{\mathrm{b}}$ & $6.32^{\mathrm{d}}$ & $5.53^{\mathrm{c}}$ & $6.77^{\mathrm{d}}$ & $1.50^{\mathrm{a}}$ \\
$\mathrm{R}-55$ & $7.88^{\mathrm{c}}$ & $5.89^{\mathrm{b}}$ & $7.22^{\mathrm{c}}$ & $7.47^{\mathrm{c}}$ & $7.88^{\mathrm{c}}$ & $7.53^{\mathrm{c}}$ & $1.00^{\mathrm{a}}$ \\
\hline
\end{tabular}

Means followed by the lowercase letters in the same row indicate a significant difference $(\mathrm{P}<0.05)$.

Table 3. Antimicrobial activity of crude bacteriocin from dadih's lactic acid bacteria against Staphylococcus aureus treated with various enzymes.

\begin{tabular}{crrcc}
\hline \multirow{2}{*}{ Strains } & \multicolumn{4}{c}{ Inhibition zone $(\mathrm{mm})$} \\
\cline { 2 - 5 } & Control & Amylase & Trypsin & Proteinase K \\
\hline R-19 & $3.32^{\mathrm{b}}$ & $13.46^{\mathrm{c}}$ & $0^{*}$ & $0^{*}$ \\
$\mathrm{R}-32$ & $3.43^{\mathrm{b}}$ & $6.80^{\mathrm{c}}$ & 0 & 0 \\
$\mathrm{R}-41$ & $3.53^{\mathrm{b}}$ & $9.00^{\mathrm{c}}$ & 0 & 0 \\
$\mathrm{R}-43$ & $5.78^{\mathrm{b}}$ & $9.66^{\mathrm{c}}$ & 0 & 0 \\
$\mathrm{R}-45$ & $7.66^{\mathrm{b}}$ & $7.23^{\mathrm{b}}$ & 0 & 0 \\
$\mathrm{R}-55$ & $7.43^{\mathrm{c}}$ & $4.51^{\mathrm{b}}$ & 0 & 0 \\
\hline
\end{tabular}

${ }^{\star}$ Lost antimicrobial activity. Means followed by the lowercase letters in the same column indicate a significant difference $(\mathrm{P}<0.05)$. zones even though the $\mathrm{pH}$ of the supernatant was adjusted to 11. The results illustrated in Table 2 showed that bacteriocin is a protein or peptide resistant to high temperature. The antimicrobial potential of heat-killed supernatant supports the thermostable nature of the antimicrobial compounds (Perez et al., 2014; Chikindas et al., 2018).

Additionally, the data in Table 2 also showed that the compounds that are probable to be bacteriocin presented in the supernatants were still resistant to temperatures up to $121^{\circ} \mathrm{C}$, even though there was a significant decrease in their antimicrobial activity $(p<0.05)$. Cell-free supernatant from the six dadih's LAB is shown to induce antimicrobial activity, resistant to various heating temperatures and $\mathrm{pH}$. The sensitivity of the produced bacteriocin was further tested using various enzymes, and the results are presented in Table 3. These results indicated that treatment with amylase resulted in the loss of antimicrobial activity of crude bacteriocin against $S$. aureus and suggested that the component of the crude bacteriocin responsible for the antimicrobial effect is not starch but protein. This statement was supported by the loss of antimicrobial activity of crude bacteriocin treated with proteolytic enzymes such as trypsin and proteinase $\mathrm{K}$. Thus, the current results showed that the bacteriocin produced by LAB is a highly thermostable proteinaceous compound with antimicrobial activity even after autoclaving at $121^{\circ} \mathrm{C}$ (Perez et al., 2014). Most of the LAB bacteriocins are peptide compounds, heat resistant, cationic, and amphiphilic (Zacharof \& Lovitt, 2012).

The antimicrobial activities of the crude bacteriocin against S. aureus (Figure 2) revealed that the six LAB strains produce bacteriocin able to inhibit $S$. aureus growth with different inhibition zones and suggesting that this antimicrobial activity is strain-dependent. Similarly, some researchers reported that bacteriocin isolated from various fermented foods can suppress S. aureus growth (Abanoz \& Kunduhoglu, 2018). The greatest antimicrobial activity against $S$. aureus was found in R-55, which showed high antimicrobial activity against Listeria monocytogenes, but it showed relatively low antimicrobial activity against $E$. coli (Pato et al., 2020). This fact indicated that the R-55 strain selectively has a higher antimicrobial activity against gram-positive bacteria than gram-negative bacteria (Bharti et al., 2015; Saeed et al., 2014).

The molecular weight of bacteriocins isolated and purified from St. faecalis subsp. liquefaciens R-55 is presented in Figure 3.

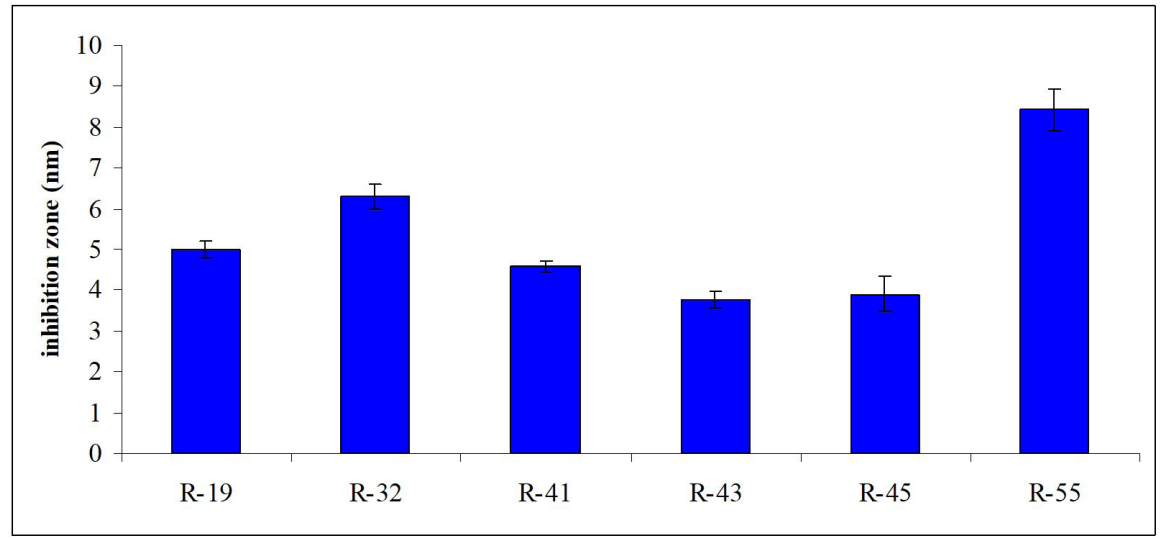

Figure 2. Antimicrobial activity of crude bacteriocin from dadih's lactic acid bacteria against Staphylococcus aureus. 


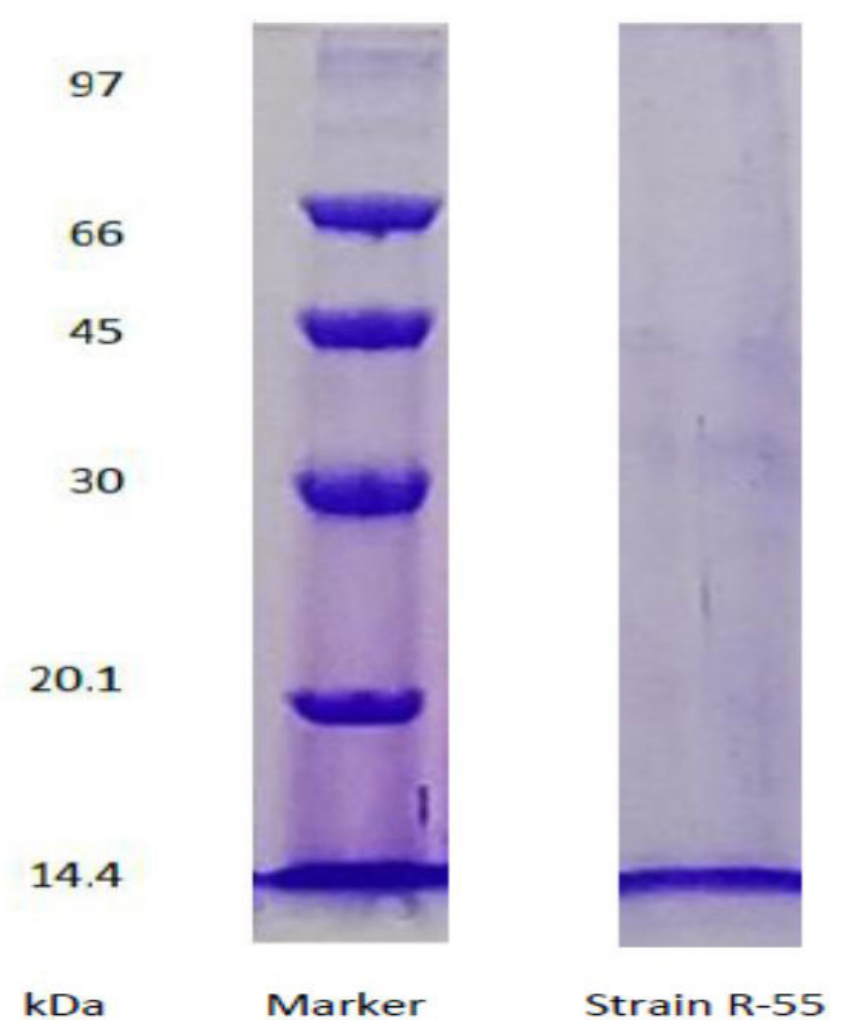

Figure 3. SDS-PAGE analyses for molecular weight of bacteriocin produced by St. faecalis subsp. liquefaciens R-55.

Based on SDS-PAGE analysis, it is found that the molecular weight of this bacteriocin was $14.4 \mathrm{kDa}$. The bacteriocins produced by several LAB vary to a great extent depending on the genus and species. Some bacteriocins have a molecular weight of greater, less, or almost the same as the molecular weight of bacteriocins produced by the R- 55 strain. The molecular weight of bacteriocins from Lactobacillus plantarum isolated from Chinese pikel was almost the same as the bacteriocin molecular weight produced by strain R-55, namely $16.5 \mathrm{kDa}$ (Zhou et al., 2014). However, Lactobacillus lactis isolated from the marine environment produced bacteriocin with a molecular weight of $94 \mathrm{kDa}$, much greater than that produced by R-55. Most LAB bacteriocins are peptide compounds with small molecular weights of less than $10 \mathrm{kDa}$ (Zacharof \& Lovitt, 2012). Enterococcus faecalis KT11 produced bacteriocin with a molecular weight of $3.5 \mathrm{kDa}$ (Abanoz \& Kunduhoglu, 2018), and Lactobacillus virisdescence NICM 2167 released bacteriocin with a molecular weight of $8.3 \mathrm{kDa}$ (Sure et al., 2016). The bacteriocin produced by Pediococcus pentosaceus zy B isolated from the intestine of Mimachlamys nobilis had a molecular weight of $2.22 \mathrm{kDa}$ (Zhang et al., 2020). Plantaricin produced from Lactobacillus plantarum IIA-1A5 showed a size of about $9.6 \mathrm{kDa}$ (Fatmarani et al., 2018).

\section{Conclusions}

The current study showed that $12 \mathrm{LABs}$ were isolated from dadih, and all of them could suppress the growth of $S$. aureus with various inhibition zone. The antimicrobial activity of $L A B$ against $S$. aureus is mainly due to the production of organic acids, especially lactic acid by strains R-8, R-14, and R-49 or the production of bacteriocins by strains R-19, R- 32, R-41, R-43, $\mathrm{R}-45$, and R-55. The bacteriocin derived from R-55 showed the highest antimicrobial activity against $S$. aureus among the bacteriocin-producing LAB. The molecular weight of bacteriocin produced by R- 55 was $14.4 \mathrm{kDa}$. This study concluded that dadih is a suitable source for the production of $\mathrm{LAB}$, which can produce the antimicrobial bacteriocin to be used in the preservation of food against the pathogenic S. aureus.

\section{Acknowledgements}

The research was funded by the Directorate of Research and Community Service, Ministry for Research, Technology and Higher Education of the Republic of Indonesia with Contract Number: 774/UN.19.5.1.3/PT.01.03/2019.

\section{References}

Abanoz, H. S., \& Kunduhoglu, B. (2018). Antimicrobial activity of a bacteriocin produced by enterococcus faecalis kt11 against some pathogens and antibiotic-resistant Bacteria. Korean Journal for Food Science of Animal Resources, 38(5), 1064-1079. http://dx.doi. org/10.5851/kosfa.2018.e40. PMid:30479512.

Argudín, M. Á., Mendoza, M. C., \& Rodicio, M. R. (2010). Food poisoning and staphylococcus aureus enterotoxins. Toxins, 2(7), 1751-1773. http://dx.doi.org/10.3390/toxins2071751. PMid:22069659.

Bharti, V., Mehta, A., Singh, S., Jain, N., Ahirwal, L., \& Mehta, S. (2015). Bacteriocin: a novel approach for preservation of food. International Journal of Pharmacy and Pharmaceutical Sciences, 7(9), 20-29.

Boucher, H. W., \& Corey, G. R. (2008). Epidemiology of methicillinresistant Staphylococcus aureus. Clinical Infectious Diseases, 46(Suppl. 5), S344-S349. http://dx.doi.org/10.1086/533590.

Carroll, D. E., Marr, I., Huang, G. K. L., Holt, D. C., Tong, S. Y. C., \& Boutlis, C. S. (2017). Staphylococcus aureus prostatic abscess: a clinical case report and a review of the literature. BMC Infectious Diseases, 17(1), 509. http://dx.doi.org/10.1186/s12879-017-2605-4. PMid:28732492.

Chambers, H. F. (1997). Methicillin resistance in staphylococci: molecular and biochemical basis and clinical implications. Clinical Microbiology Reviews, 10(4), 781-791. http://dx.doi.org/10.1128/ CMR.10.4.781. PMid:9336672.

Chikindas, M. L., Weeks, R., Drider, D., Chistyakov, V. A., \& Dicks, L. M. (2018). Functions and emerging applications of bacteriocins. Current Opinion in Biotechnology, 49, 23-28. http://dx.doi.org/10.1016/j. copbio.2017.07.011. PMid:28787641.

Dicks, L. M. T., van Staden, A. D. P., \& Klumperman, B. (2017). Bacteriocins and nanotechnology. In R. Boukherroub, S. Szunerits \& D. Drider (Eds.), Functionalized nanomaterials for the management of microbial infection: a strategy to address microbial drug resistance. USA: Elsevier Inc. http://dx.doi.org/10.1016/B978-0-323-41625-2.00007-7

Fatmarani, R., Arief, I. I., \& Budiman, C. (2018). Purification of bacteriocin from Lactobacillus plantarum IIA-1A5 grown in various whey cheese media under freeze dried condition. Tropical Animal Science Journal, 41(1), 53-59. http://dx.doi.org/10.5398/tasj.2018.41.1.53.

Garcia-Graells, C., Antoine, J., Larsen, J., Catry, B., Skov, R., \& Denis, O. (2012). Livestock veterinarians at high risk of acquiring methicillinresistant Staphylococcus aureus ST398. Epidemiology and Infection, 140(3), 383-389. http://dx.doi.org/10.1017/S0950268811002263. PMid:22082716.

Ho, P. L., Chow, K. H., Lai, E. L., Law, P. Y. T., Chan, P. Y., Ho, A. Y. M., Ng, T. K., \& Yam, W. C. (2012). Clonality and antimicrobial 
susceptibility of Staphylococcus aureus and methicillin-resistant S. aureus isolates from food animals and other animals. Journal of Clinical Microbiology, 50(11), 3735-3737. http://dx.doi.org/10.1128/ JCM.02053-12. PMid:22895044.

Hosono, A., Tanabe, T., \& Otani, H. (1990a). Binding properties of lactic acid bacteria isolated from kefir milk with mutagenic amino acid pyrolyzates. Milchwissenschaft. Milk Science International, 45(10), 647-651.

Hosono, A., Wardojo, R., \& Otani, H. (1990b). Binding of amino acid pyrolyzates by lactic acid bacteria isolated from "dadih". Lebensmittel Wissenschaft + Technologie $=$ Food science + technology, 23(2), 149-153 .

Hu, D. L., \& Nakane, A. (2014). Mechanisms of staphylococcal enterotoxininduced emesis. European Journal of Pharmacology, 722(1), 95-107. http://dx.doi.org/10.1016/j.ejphar.2013.08.050. PMid:24184671.

Kadariya, J., Smith, T. C., \& Thapaliya, D. (2014). Staphylococcus aureus and staphylococcal food-borne disease: an ongoing challenge in public health. BioMed Research International, 2014, 827965. http:// dx.doi.org/10.1155/2014/827965. PMid:24804250.

Kitagawa, N., Otani, T., \& Inai, T. (2019). Nisin, a food preservative produced by Lactococcus lactis, affects the localization pattern of intermediate filament protein in $\mathrm{HaCaT}$ cells. Anatomical Science International, 94(2), 163-171. http://dx.doi.org/10.1007/s12565018-0462-x. PMid:30353456.

Othman, H., Elbaba, A., Abdelsamei, H., Abdou, A., \& Ibrahim, E. (2017). Evaluation the effect of Lactobacillus acidophilus probiotic culture over Staphylococcus aureus during the production and storage of acidophilus yoghurt. Benha Veterinary Medical Journal, 32(1), 127-131. http://dx.doi.org/10.21608/bvmj.2017.31197.

Pato, U., Djohan, V. S., Khairunnisa, F., \& Hasibuan, R. D. H. (2017). Antibiotic resistance and antibacterial activity of dadih originated Lactobacillus Casei Subsp. Casei R-68 against food borne pathogens. Asian Journal of Microbiology, Biotechnology and Environmental Sciences, 19(3), 577-587.

Pato, U., Yusuf, Y., Fitriani, S., Jonnadi, N. N., Wahyuni, M. S., Feruni, J. A., \& Jaswir, I. (2020). Inhibitory activity of crude bacteriocin produced by lactic acid bacteria isolated from dadih against Listeria monocytogenes. Biodiversitas Journal of Biological Diversity, 21(4), 1295-1302. http://dx.doi.org/10.13057/biodiv/d210404.

Payne, S. C., \& Benninger, M. S. (2007). Staphylococcus aureus Is a major pathogen in acute bacterial rhinosinusitis: a meta-analysis. Clinical Infectious Diseases, 45(10), e121-e127. http://dx.doi. org/10.1086/522763. PMid:17968816.

Perez, R. H., Zendo, T., \& Sonomoto, K. (2014). Novel bacteriocins from lactic acid bacteria (LAB): Various structures and applications. Microbial Cell Factories, 13(Suppl 1), S1-S3. http://dx.doi.org/10.1186/14752859-13-S1-S3. PMid:25186038.

Rajaram, G., Manivasagan, P., Thilagavathi, B., \& Saravanakumar, A. (2010). Purification and characterization of a bacteriocin produced by Lactobacillus lactis isolated from marine environment. Advance Journal of Food Science and Technology, 2(2), 138-144.

Rasooly, R., \& Friedm, M. (2012). Food compounds inhibit staphylococcus aureus bacteria and the toxicity of Staphylococcus Enterotoxin A (SEA) associated with atopic dermatitis. In J. Esparza-Gordillo \& I. Dekio (Eds.), Atopic dermatitis - atopic dermatitis -disease etiology and clinical management. London: IntechOpen.

Rios, A. C., Moutinho, C. G., Pinto, F. C., Del Fiol, F. S., Jozala, A., Chaud, M. V., Vila, M. M. D. C., Teixeira, J. A., \& Balcão, V. M. (2016). Alternatives to overcoming bacterial resistances: State-of-the-art. Microbiological Research, 191, 51-80. http://dx.doi.org/10.1016/j. micres.2016.04.008. PMid:27524653.

Saeed, M., Khan, W., Shabbir, M., Khan, M., \& Atif, M. (2014). Bacteriocins as a natural antimicrobial agent in food preservation: A review. Pakistan Journal of Food Sciences, 24(4), 244-255.
Sankar, N. R., Priyanka, V. D., Reddy, P. S., Rajanikanth, P., Kumar, V. K., \& Indira, M. (2012). Purification and Characterization of Bacteriocin Produced by Lactobacillus plantarum Isolated from Cow Milk. International Journal of Microbiological Research, 3(2), 133-137.

Stiles, M. E. (1996). Biopreservation by lactic acid bacteria. In Antonie van Leeuwenhoek. International Journal of General and Molecular Microbiology, 70(2-4), 331-345.

Sure, K. P., Kotnis, P. V., Bhagwat, P. K., Ranveer, R. C., Dandge, P. B., \& Sahoo, A. K. (2016). Production and characterization of bacteriocin produced by Lactobacillus viridescence(NICM 2167). Brazilian Archives of Biology and Technology, 59, 1-7.

Syukur, S., Fachrial, E., \& Jamsari, A. (2014a). Isolation, antimicrobial activity and protein bacteriocin characterization of lactic acid bacteria isolated from Dadih in Solok, West Sumatera. Indonesia, 5, 1096-1104.

Syukur, S., Rijal, F., Jamsari, A., \& Purwati, E. (2014b). Isolation and molecular characterization of lactic acid bacteria by using 16s rRNA from fermented buffalo milk (Dadih) in Sijunjung, West Sumatera. Research Journal of Pharmaceutical, Biological and Chemical Sciences, 5(6), 873-876.

Taddesse, Z., Tiruneh, M., \& Gizachew, M. (2014). Staphylococcus aureus and its Antimicrobial Susceptibility. Global Journal of Medical Research: C Microbiology and Pathology, 14(2), 1-8.

Tong, S. Y. C., Davis, J. S., Eichenberger, E., Holland, T. L., \& Fowler, V. G. Jr. (2015). Staphylococcus aureus infections: Epidemiology, pathophysiology, clinical manifestations, and management. Clinical Microbiology Reviews, 28(3), 603-661. http://dx.doi.org/10.1128/ CMR.00134-14. PMid:26016486.

van Loo, I., Huijsdens, X., Tiemersma, E., De Neeling, A., Van De Sande-Bruinsma, N., Beaujean, D., Voss, A., \& Kluytmans, J. (2007). Emergence of methicillin-resistant Staphylococcus aureus of animal origin in humans. Emerging Infectious Diseases, 13(12), 1834-1839. http://dx.doi.org/10.3201/eid1312.070384. PMid:18258032.

Vandendriessche, S., Vanderhaeghen, W., Larsen, J., de Mendonça, R., Hallin, M., Butaye, P., Hermans, K., Haesebrouck, F., \& Denis, O. (2014). High genetic diversity of methicillin-susceptible Staphylococcus aureus (MSSA) from humans and animals on livestock farms and presence of SCCmec remnant DNA in MSSA CC398. The Journal of Antimicrobial Chemotherapy, 69(2), 355-362. http://dx.doi. org/10.1093/jac/dkt366. PMid:24072172.

Vickery, T. W., Ramakrishnan, V. R., \& Suh, J. D. (2019). The role of staphylococcus aureus in patients with chronic sinusitis and nasal polyposis. Current Allergy and Asthma Reports, 19(4), 21. http:// dx.doi.org/10.1007/s11882-019-0853-7. PMid:30859336.

Walsh, J. (2007). Food and drug administration (U.S.). In P. Robbins (Ed.), Encyclopedia of environment and society (Vol. 1, pp. 693-693). Nova York: SAGE Publications, Inc.

Zacharof, M. P., \& Lovitt, R. W. (2012). Bacteriocins produced by lactic acid bacteria a review article. APCBEE Procedia, 2, 50-56. http:// dx.doi.org/10.1016/j.apcbee.2012.06.010.

Zhang, Y., Yang, J., Liu, Y., Wu, Y., Fang, Z., Wang, Y., Sun, L., Deng, Q., Gooneratne, R., \& Xiao, L. (2020). A novel bacteriocin PEZYB1 produced by Pediococcus pentosaceus zy-B isolated from intestine of Mimachlamys nobilis: purification, identification and its anti-listerial action. $L w t, 118,108760$. http://dx.doi.org/10.1016/j. lwt.2019.108760.

Zhou, F., Zhao, H., Bai, F., Piotr, D., Liu, Y., \& Zhang, B. (2014). Purification and characterisation of the bacteriocin produced by Lactobacillus plantarum, isolated from Chinese pickle. Czech Journal of Food Sciences, 32(5), 430-436. http://dx.doi.org/10.17221/270/2013-CJFS. 